\title{
High-flow priapism after perineal trauma
}

\author{
Jonathan R. Dillman • Kyung J. Cho
}

Received: 19 August 2009 / Accepted: 2 September 2009/Published online: 29 October 2009

(C) Springer-Verlag 2009

A 16-year-old boy presented with persistent penile tumescence following perineal straddle injury. Pelvic arteriography showed a dilated right internal pudenal artery (arrowheads) and an abnormal contrast material collection at the penile base (arrow) (Fig. 1). Superselective penile arteriography demonstrated a right cavernosal artery laceration with rapid contrast material flow into adjacent erectile tissues (arrowheads) (Fig. 2). High-flow priapism due to a cavernosal artery-corpus cavernosum traumatic fistula was diagnosed and successfully treated with selective cavernosal artery embolization using autologous blood clot.

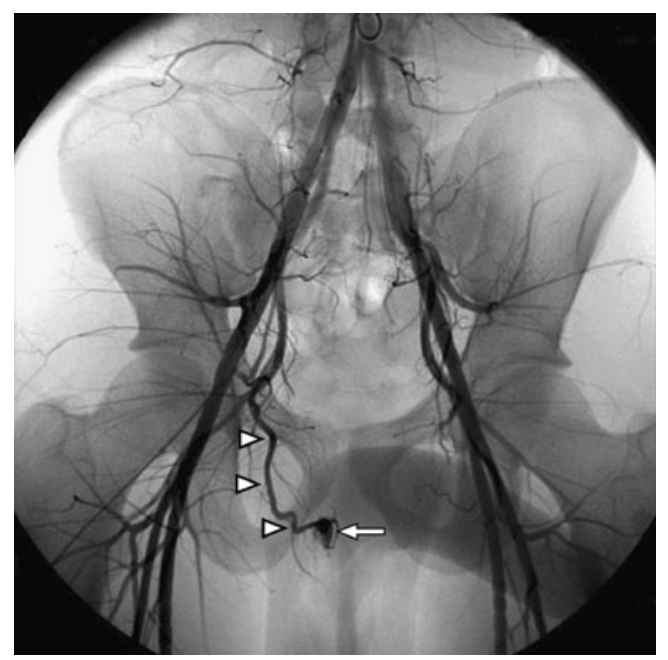

Fig. 1 Pelvic arteriogram

\section{J. R. Dillman $(\bowtie)$}

University of Michigan Health System, Department of Radiology, Section of Pediatric Radiology, C.S. Mott Children's Hospital, 1500 East Medical Center Dr.,

Ann Arbor, MI 48109-5252, USA

e-mail: jonadill@med.umich.edu

\section{K. J. Cho}

University of Michigan Health System, Department of Radiology,

Division of Vascular \& Interventional Radiology,

C. S. Mott Children's Hospital,

Ann Arbor, MI, USA

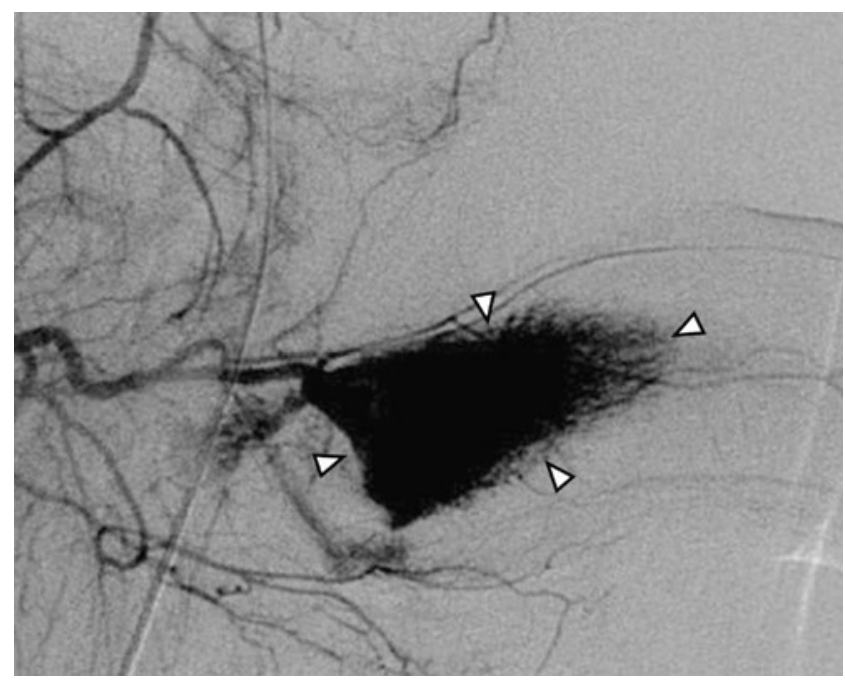

Fig. 2 Digital subtraction arteriogram of the right penile artery

Priapism, the unremitting engorgement of penile erectile tissues in the absence of sexual stimulation, may be categorized as "high" or "low" flow. High-flow priapism is due to increased penile blood flow, usually following perineal trauma with creation of an intracavernosal fistula that allows unregulated arterial blood flow into erectile tissues bypassing regulatory helicine arteries [1,2]. This form is generally painless, rarely causes penile ischemia, and may be managed with selective arterial embolization $[1,2]$. Low-flow priapism is due to penile venous outflow obstruction $[1,2]$, is typically painful, atraumatic, and may be complicated by ischemic penile necrosis and fibrosis [2]. There are numerous causes of low-flow priapism in children, including sickle cell disease, leukemia, and a variety of hypercoaguable states [2].

\section{References}

1. Stock KW, Jacob AL, Kummer M et al (1996) High-flow priapism in a child: treatment with superselective embolization. AJR 166:290-292

2. Miller SF, Chait PG, Burrows PE et al (1995) Posttraumatic arterial priapism in children: management with embolization. Radiology 196:59-62 